\title{
Evolution and complexity of government policies to protect the health of undocumented/illegal migrants in Thailand - the unsolved challenges
}

This article was published in the following Dove Press journal:

Risk Management and Healthcare Policy

I5 April 2017

Number of times this article has been viewed

Rapeepong

Suphanchaimat ${ }^{1,2}$

Weerasak Putthasri'

Phusit Prakongsai ${ }^{1,3}$

Viroj Tangcharoensathien'

International Health Policy Program (IHPP), The Ministry of Public Health, Nonthaburi, ${ }^{2}$ Banphai Hospital, Khon Kaen, ${ }^{3}$ Bureau of International Health $(\mathrm{BIH})$, The Ministry of Public Health, Nonthaburi, Thailand
Correspondence: Rapeepong Suphanchaimat

International Health Policy Program (IHPP), Ministry of Public Health,

Tiwanon Road, Nonthaburi II 000, Thailand

Tel +6625902366

Fax +6625902385

Email rapeepong@ihpp.thaigov.net
Background: Of the 65 million residents in Thailand, >1.5 million are undocumented/illegal migrants from neighboring countries. Despite several policies being launched to improve access to care for these migrants, policy implementation has always faced numerous challenges. This study aimed to investigate the policy makers' views on the challenges of implementing policies to protect the health of undocumented/illegal migrants in light of the dynamics of all of the migrant policies in Thailand.

Methods: This study used a qualitative approach. Data were collected by document review, from related laws/regulations concerning migration policy over the past 40 years, and from in-depth interviews with seven key policy-level officials. Thematic analysis was applied.

Results: Three critical themes emerged, namely, national security, economic necessity, and health protection. The national security discourse played a dominant role from the early $1900 \mathrm{~s}$ up to the 1980s as Thailand attempted to defend itself from the threats of colonialism and communism. The economic boom of the 1990s created a pronounced labor shortage, which required a large migrant labor force to drive the growing economy. The first significant attempt to protect the health of migrants materialized in the early 2000s, after Thailand achieved universal health coverage. During that period, public insurance for undocumented/illegal migrants was introduced. The insurance used premium-based financing. However, the majority of migrants remained uninsured. Recently, the government attempted to overhaul the entire migrant registry system by introducing a new measure, namely the One Stop Service. In principle, the One Stop Service aimed to integrate the functions of all responsible authorities, but several challenges still remained; these included ambiguous policy messages and the slow progress of the nationality verification process.

Conclusion: The root causes of the challenges in migrant health policy are incoherent policy direction and objectives across government authorities and unclear policy messages. In addition, the health sector, especially the Ministry of Public Health, has been de facto powerless and, due to its outdated bureaucracy, has lacked the capacity to keep pace with the problems regarding human mobility.

Keywords: migrant, health insurance, Thailand, policy formulation, policy process

\section{Background}

Health of migrants is one of the major contemporary discourses in global policy dialogue. It is estimated that $>214$ million people $(\sim 3.1 \%$ of the global population) are living outside their country of origin, and the volume of international migrants worldwide might exceed 405 million by $2050 .{ }^{1}$ The accelerating trend in human mobility is ascribed to numerous factors, such as economic pressures, advances in transportation 
technology, shortages of labor in developed countries, political conflict and violence, and human trafficking. ${ }^{1}$

Accordingly, many countries, and international development agencies, have called for the protection of the health of migrants, as is evidenced by a number of high-level meetings, such as the United Nations General Assembly meeting in 2006, and the World Health Assembly (WHA) Resolutions in 2007 and 2008 (WHA60.26 and WHA61.17). ${ }^{2-4}$ In addition, migrant health is incorporated into the tenets of Universal Health Coverage (UHC). The post-2015 Sustainable Development Goals (SDGs) also stated that countries seeking to achieve UHC must ensure that "no one" is left behind. ${ }^{5}$ Although there has been marked progress toward better health and social protection for migrants "in principle," there are still numerous challenges concerning how to effectively translate this concept into action. This is because "migrant health" is extremely dynamic and necessitates multisectoral cooperation.

Thailand is an upper-middle-income country in Southeast Asia. The country's geographical location, on the seam between the Indian and Pacific Oceans, makes the country the center of the Indochinese Peninsula. These two characteristics attract a large number of migrants, especially from its neighboring countries, Cambodia, Lao PDR, and Myanmar, the so-called CLM nations. Identifying the true number of non-Thais residing in the country is a complex challenge for Thai policy makers. The most recent census, conducted in 2010, estimated that the number of non-Thai nationals in Thailand was $\sim 3.2$ million. The majority of them were CLM migrant workers, and dependents, who had crossed the border illegally. ${ }^{6,7}$

Although these undocumented/illegal immigrants should, in theory, be deported, such "hard measures" have not commonly been used; this is because it is widely accepted that these migrants are a key contributor to the Thai economy. The International Labor Organization (ILO) reported that, in 2007, migrants contributed $>6 \%$ of the Thai gross domestic product. ${ }^{8}$ Such a reason has led the Thai government to attempt to register these undocumented/illegal migrants through a process, called nationality verification (NV). Those taking part in the NV process are called NV migrants, and they will be issued a work permit and will be insured through the "Health Insurance Card Scheme" (HICS), managed by the Ministry of Public Health (MOPH). ${ }^{7}$ Descriptions of these measures are detailed later in the "Results" section.

Despite a, seemingly, comprehensive approach to protect the health of undocumented/illegal migrants in Thailand, in reality, there still exist a number of gaps: a significant number of migrants never enroll in, or enroll but subsequently drop out of, the scheme, and there is substantial room for differing legal interpretations concerning the rights of migrants. ${ }^{9}$

This study sought to examine the challenges policy makers experienced in implementing policies to protect health of undocumented/illegal migrants in the context of the evolving and competing political dynamics in Thailand. Although there have been some research on migrant policies in Thailand, a comprehensive investigation, taking into account the history and dynamicity of all aspects of migrant policies, is still lacking. Most previous studies explored migrant policies in separate angles, without addressing the history of, and interaction between, all ministerial policies. Some examples of existing research are a study by Srithamrongsawat et al, which described the evolution of health insurance policies for undocumented/illegal migrants in Thailand since $2004,{ }^{10}$ and a study by Paisanpanichkul, which reviewed related laws concerning rights to health of stateless population. ${ }^{11}$ Another study by Paitoonpong and Chalamwong demonstrated the economic impact of labor migration in Thailand. ${ }^{12}$ It is hoped that the discoveries from the present study can provide policy makers and academics in the field with a better understanding of migrant policies, particularly in the health aspect, not only in Thailand but also in other countries where migrant health is in the spotlight.

\section{Methods}

\section{Conceptual framework and scope of the study}

The conceptual framework was adapted from the concept of Leichter, suggesting that the implementation of policy was influenced by several factors, such as the transient and idiosyncratic atmosphere surrounding a policy (situation factors), the edifice of the responsible agencies (structural factors), the value commitments of a community (cultural factors), and external events or values outside of domestic politics (external factors). ${ }^{13}$ This framework was used to construct question guide before embarking the fieldwork (deductive approach). Then the researchers gathered data from the field and extracted key themes from these data (inductive approach; Figure 1).

It should be noted that this study limited itself to studying undocumented/illegal low-skilled CLM migrants and their dependents, who were potential beneficiaries of the HICS. The majority of them are of working age $(\sim 80 \%$ are at the age of 15-50 years) and mostly engaged in low-skilled labor jobs, such as fishery and construction. ${ }^{6}$ Note that the term "undocumented/illegal migrants" in this sense refers to those 


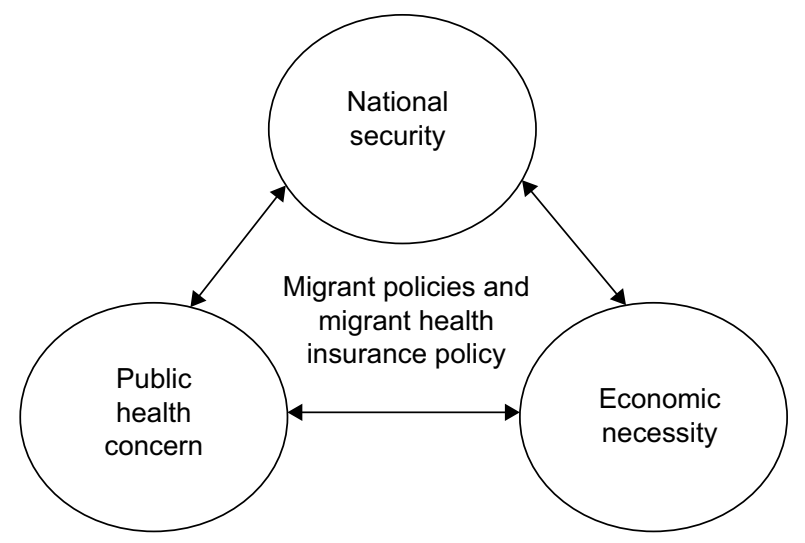

Figure I Conceptual framework.

Note: Data from Leichter HM. A Comparative Approach to Policy Analysis: Health Care Policy in Four Nations. Cambridge: Cambridge University Press; 1979.13

crossing the border without valid travel documents as well as their dependents born in Thailand but failing to register for a birth certificate. However, this does not mean that these migrants totally lack any document to identify themselves. In practice, the state always provided some documents to register/identify undocumented/illegal migrants, but the registration process did not necessarily guarantee that their precarious citizenship status would be fully legalized (see more details in the "Results" section). Other groups of nonThais, such as tourists, expatriates, foreign white-collar workers covered by social or private health insurance, and refugees in shelters, were not the topic of this article.

\section{Data collection and tools}

Document review and in-depth interviews were used as the main data collection techniques. For the document review, Thai laws and regulations concerning migrant issues over the past 40 years were retrieved and reviewed. The reviewed documents included the Thai Constitutions, Nationality Acts, Immigration Acts, and Alien Work Acts. Subordinate laws such as ministerial announcements, relevant minutes, and proceedings from official meetings and conferences were also explored. Additional references were sought from the archives of the MOPH.

For the in-depth interviews, seven key informants who were involved in the formulation of the HICS and relevant migrant policies were purposively selected. Initially, the researchers could only identify five interviewees (namely M1, M2, M3, M4, and M7), then two additional interviewees (M5 and M6) were recruited through snowball sampling.

Each interview lasted around 45 minutes and was audiotaped and transcribed with the consent of the interviewees. Re-interviews were conducted until the data were saturated. All interviews were carried out face-to-face at the informants' workplace. Most interviewees were males, aged between 50 and 60 years. The role and responsibilities regarding migrant policies and information about workplace of the interviewees are summarized in Table 1

\section{Data analysis}

As briefly mentioned earlier in the "Conceptual framework and scope of the study" section, thematic analysis was exercised through both deductive and inductive approaches. In the deductive approach, data were coded manually and mapped and charted against the framework. The respondents were asked to describe the rationale of migrant health policies in relation to each element of the framework and to share their opinions about the successes, failures, and continuing challenges of the policies. Then, in each deductive theme in the framework, the inductive coding was applied to identify crosscut contents or high-level themes. Finally, it is found that migrant health policies in Thailand were influenced by three interrelated factors, namely 1) national security, 2) economic necessity, and 3) health protection, as detailed in the "Results" section.

The final report was circulated to all interviewees in mid2015 to confirm the validity of the results before completing the final draft of the report. This process allowed the researchers to triangulate the accuracy of the data interpretation and to re-check with the respondents if they agreed to have their quotes anonymously presented in the final report.

Table I Characteristics of the key informants

\begin{tabular}{|c|c|c|}
\hline Code & Current workplace & $\begin{array}{l}\text { Role and responsibility } \\
\text { regarding migrant health } \\
\text { policies }\end{array}$ \\
\hline MI & $\begin{array}{l}\text { Office of the Permanent } \\
\text { Secretary, the MOPH }\end{array}$ & $\begin{array}{l}\text { Involved in the formulation of } \\
\text { HICS }\end{array}$ \\
\hline M2 & $\begin{array}{l}\text { Independent academic } \\
\text { institute }\end{array}$ & $\begin{array}{l}\text { Involved in the policy discourse } \\
\text { regarding whether the } \\
\text { Universal Coverage Scheme } \\
\text { for Thai nationals should be } \\
\text { expanded to cover non-Thais }\end{array}$ \\
\hline M3 & $\begin{array}{l}\text { Office of the Permanent } \\
\text { Secretary, the MOPH }\end{array}$ & $\begin{array}{l}\text { Involved in the formulation of } \\
\text { HICS }\end{array}$ \\
\hline M4 & $\begin{array}{l}\text { Office of the Permanent } \\
\text { Secretary, the MOPH }\end{array}$ & $\begin{array}{l}\text { Involved in the formulation of } \\
\text { HICS }\end{array}$ \\
\hline M5 & $\begin{array}{l}\text { Office of the Permanent } \\
\text { Secretary, the MOL }\end{array}$ & $\begin{array}{l}\text { Involved in the implementation } \\
\text { of the migrant recruitment } \\
\text { policy }\end{array}$ \\
\hline M6 & $\begin{array}{l}\text { Faculty of Law in one of the } \\
\text { public universities }\end{array}$ & $\begin{array}{l}\text { Member of the National } \\
\text { Reform Council during the } \\
\text { junta }\end{array}$ \\
\hline M7 & $\begin{array}{l}\text { Office of the Permanent } \\
\text { Secretary, the MOPH }\end{array}$ & $\begin{array}{l}\text { Supervising the reimbursement } \\
\text { for contracted hospitals under } \\
\text { the HICS }\end{array}$ \\
\hline
\end{tabular}

Abbreviations: MOPH, Ministry of Public Health; MOL, Ministry of Labor; HICS, Health Insurance Card Scheme. 


\section{Results}

\section{National security}

On this topic, three subthemes were identified, namely 1) Confusion in words - not just a matter of words, 2) Denial of the principle of jus soli citizenship - a legacy of previous laws, and 3) Current strategies for managing citizenship status problems.

\section{Confusion in words - not just a matter of words}

The Immigration Act (1979) has served as the supreme umbrella for almost all migration policies in Thailand. The word "alien" is used in the Act to refer to "any ordinary person who does not have Thai nationality." 14 According to Napaumporn, the term "aliens" could be classified into two groups: 1) people traveling from another country and 2) people living in their country of residence since birth but failing to obtain citizenship of the host country. ${ }^{15}$ In the Thai context, a specific Thai word "tang chad" is commonly assigned to "foreigners" as a whole, whereas Caucasian (white) foreigners are often called "farang." By contrast, in the everyday perception of most Thai people, the word "tang $d a o^{\prime}$ is reserved for cross-border migrants from developing countries, particularly from the CLM nations. This perception deviates from what is written in the Immigration Act, and at times the words "foreigners," "aliens," and "migrants" are used interchangeably, not only in the lay language but also in official policy documents. ${ }^{14}$

The bottom line of migrant health problems in Thailand is that many people are overly afraid of using the term, "aliens," and try to replace it with more beautiful words like, "foreigners" or "migrants." This made us forget the non-nationals who cannot identify their country of origin. It is like hiding a problem; using a hand to cover the sun. Can we hide it?" [M6]

\section{Denial of the principle of jus soli citizenship - a legacy of previous laws}

Historically, Thailand and many other countries in Southeast Asia did not have a strong concept of the nation-state until the late 1800 s or early 1900s. During that time, the Kingdom of Siam (Thailand) started to define its boundaries with neighboring countries in response to pressure from the Western colonial empires. Thai state administration was reformed to increase centralized enforcement power, in line with the format of Western governments. Accordingly, in 1913, the first written Nationality Act was promulgated. During that time, the only criteria for obtaining "Thai nationality" was an individual's place of birth, regardless of their parents' nationality status (jus soli enjoyment). ${ }^{15-17}$

The evolution of nationality laws in Thailand has been very sensitive to both internal and external politics. One of the most important milestones in the history is "the Regulation of Revolution Party No.337" (called Por Wor 337), proclaimed in December 1972. ${ }^{18}$ The most distinctive feature of Por Wor 337 is that it revoked the Thai nationality of persons who were born in Thailand of an alien father or an alien mother with non-permanent residence. Por Wor 337 was introduced due to the fear of communism in Southeast Asia, especially during the Indo-China war. The rationale behind this was that it would bar the children of people from communist countries from obtaining Thai nationality. ${ }^{18}$ Although Por Wor 337 was substituted by the Nationality Act (second revision) in 1992 , the concept of restricted "jus soli" still prevails. This is demonstrated by Section 7 bis of the current 2008 Nationality Act (fourth revision), which stipulates that a baby born in Thailand of alien parents will not acquire Thai nationality if, at the time of birth, either of his/her parents is a person being granted leniency for temporary residence in the country or entered the country without permission, and that baby will be regarded as an "illegal immigrant" unless an applicable law specifies otherwise. ${ }^{18,19}$

\section{Current strategies for managing citizenship status problems}

Despite the stipulation in the 1979 Immigration Act that illegal immigrants must be deported, chronic labor shortages have meant that Thailand's economy has been hugely reliant on these migrant workers. For this reason, most previous governments exercised the power specified in Section 17 of the 1979 Immigration Act, indicating that in certain circumstances, the Minister, with Cabinet approval, may permit any group of aliens to stay in the Kingdom under certain conditions, or may consider exempting them from the necessity of conforming with the Act. ${ }^{14}$

Between 1992 and 2012,>20 such cabinet resolutions were promulgated. These lenient measures all share the common characteristics of demanding that Thai employers take their illegal/undocumented migrant workers to 1) register with the Ministry of Interior (MOI) and 2) to be issued with a work permit by the Ministry of Labour (MOL). Once registered with the MOI, migrants can obtain the " 00 " card, which is similar to the national identity card (ID card) of Thai citizens but with the difference that the numbers on the migrant ID cards begin with " 00 ." These migrants are 
then required to complete the $\mathrm{NV}$ process, which requires collaboration between the Thai government and the government of migrants' home countries. Once the NV process is completed, they will be called NV migrants and obtain a temporary passport from the authorities of their country of origin. In other words, the NV is a legalization process for illegal/undocumented migrants. ${ }^{20}$

Nevertheless, there were nuanced differences between the resolutions issued in different periods. For example, the Cabinet Resolution of May 26, 2009, required illegal migrants and dependents aged $\leq 15$ years to be registered with the MOI within a couple of months. However, due to administrative procrastination, a number of migrant workers in the fishery business failed to complete the registration within the given time. The government at that time extended the registration period to September 30, 2009, but the new extension was only made for migrant workers in the fishery industry, without including their dependents. The Lawyers Council of Thailand complained that the measures were somewhat "confusing" and "unsystematic," which was consistent with the opinion of the respondent below. ${ }^{20}$

It is wrong to talk about migrant policy in Thailand, because there have never been migrant policies in this country [...] Policymakers in this country have never seen beyond the end of their noses, and have never thought of addressing structural problems. [M2]

In 2012, the number of illegal CLM migrants, who registered for the " 00 " ID card, soared to over a million, and this trend did not seem to be fading. ${ }^{7}$ Aside from internal factors, external pressure has also played an important role in influencing the Thai government to reorient its migrant policies. In 2010, Thailand was listed in Tier 2-Watchlist of the Trafficking in Persons Report (TIPS), the second worst level possible. ${ }^{21}$ These factors forced the government to show significant efforts in dealing with the problems of illegal migrants and human trafficking. ${ }^{22}$ Therefore, the National Security Council (NSC) endorsed a new national strategy, namely "the National Strategy for the Systematic Management of Cross-border Migration," in 2012. In essence, the strategy did not provide new measures to tackle legal problems related to migration. In fact, it reiterated measures from the previous cabinet resolutions while also giving a strong message that those who failed to register with the authorities would be subject to deportation. The key goals of this strategy were 1) to facilitate the recruitment and employment of legalized migrant workers from CLM countries (in line with the Memorandum of Understanding [MOU] policy, which is described in the subsequent topic), 2) to expedite the NV process, and 3) to make it clear that over-stayers and non-registered illegal migrants would be subject to suppression..$^{23}$ It is clear that the 2012 strategy did not prioritize human rights, as was flagged by the key informant below.

The 2012 strategy belongs to the right-wing hawks. It rarely touched this (human rights) issue. In the international meeting of $[\ldots]$ organised by $[\ldots]$, the strategy was criticised shamefully. [M6]

\section{Economic necessity}

Within the topic of economics, two subthemes emerged: 1) Lenient measures to permit illegal/undocumented migrants to work in Thailand and 2) an MOU policy - an innovative approach that has faced numerous challenges.

\section{Lenient measures for allowing illegal/ undocumented migrants to work in Thailand}

The Office of Foreign Workers Administration under the MOL is the main body responsible for issuing work permits to migrant workers and assisting Thai employers in recruiting cross-border migrant workers. ${ }^{12}$ The Alien Work Act (1978) has provided the framework for migrant worker recruitment for years. For high-skilled foreign workers, such as engineers, teachers, and businessmen, the issuance of a work permit was straightforward.

The Alien Work Act dictates that an alien, who wishes to work in Thailand, must have expertise in the relevant field of work and must not be insane or mentally ill or experience any of the diseases, namely leprosy, elephantiasis, stage 3 syphilis, drug addiction, active tuberculosis, or alcoholism. Furthermore, aliens cannot apply for work in any of the 39 "reserved" occupations.

The 39 reserved occupations are specified in the Royal Decree of 1979, the so-called negative list. In principle, occupations in this list are reserved for Thai nationals because they are linked with Thai tradition and culture. ${ }^{24}$ Some examples of these occupations are wood carving, manual cloth weaving, tour guiding, and various kinds of "manual labour."

However, the situation changed in the early 1990s. The 1988 military coup and violent suppression of the prodemocracy movement in Myanmar begot a large influx of more than a hundred thousand migrants to Thailand. This situation coincided with a period of rapid economic growth in Thailand, which resulted in labor shortages, particularly in dangerous, dirty, and demeaning work, known as "3Ds" 
jobs. ${ }^{15,25}$ Since Thai workers were more reluctant to engage in 3D jobs, low-skilled migrant workers from CLM countries became a viable source of labor for Thai entrepreneurs. ${ }^{26}$

Adhering strictly to the Alien Work Act (1978) would mean that illegal/undocumented migrants cannot apply for a work permit. This deadlock forced the government to find a solution that would enable these workers to work legitimately in the country, in the same way as the tactic exercised by the MOI, where the amnesty laws (via the Cabinet Resolutions and the NV) were used as a tool to tackle legal problems.

The MOL issued the Ministry of Labour Decree in 2004 (the same period when the "00" ID card program was initiated), allowing illegal/undocumented migrants to work in 27 occupations as specified in the Decree, the so-called positive list. ${ }^{27}$

In essence, these 27 occupations could be categorized into two groups: 1) manual labor and 2) domestic service. Of note is that this regulation applied only to workers from CLM countries, not to migrants from other countries. ${ }^{28}$

\section{MOU policy - an innovative approach that has faced numerous challenges}

The NV policy and amnesty laws were temporary measures for dealing with CLM migrants who had already crossed the border, but there was a need to have more proactive measures to legally recruit low-skilled migrants. Hence, the MOU policy was instigated in 1999. This was a mutual agreement between Thailand (as receiving country) and CLM nations (as sending countries). ${ }^{29}$ However, the actual implementation of the MOU policy was significantly delayed after the 1999 policy decision because of cooperation challenges and the limited capacity of relevant authorities to manage the process outlined in the MOU. This is evidenced by the fact that the deployment of MOU migrant workers from Cambodia and Lao PDR did not happen until 2006 and was deferred in Myanmar until 2009. ${ }^{30}$

Moreover, the process for recruiting migrant workers under the MOU is quite cumbersome. It is estimated that the minimum time from sending a request to the Thai Department of Employment (DOE) to the arrival of a worker is 89 days for migrants from Myanmar and $\sim 60$ days for Cambodian and Laotian migrants. ${ }^{29}$ The approval process of all three labor-exporting countries is sluggish because a vast amount of paperwork needs to be completed, in both the intergovernmental and intragovernmental spheres. ${ }^{26}$ The ILO (2015) reported that the huge administrative burden and lengthy approval processes indirectly force employers and workers to rely on private intermediaries or brokers. ${ }^{29}$
I just learnt that there is a quota (for migrant recruitment), but I have no idea how it (the MOL) allocates this quota. If I request five housemaids, I am not sure whether this request will be checked. [M2]

It should be noted that both MOU migrants and NV migrants share similar characteristics in terms of the length of time they are permitted to work in Thailand and the requirement to obtain certain essential documents. Regarding the length of time that they are permitted to work in Thailand, migrants in both the groups are normally granted temporary residence for 2 years with the opportunity to extend for a further 2 years, resulting in a maximum of 4 years. They must renew their work permit every year. After 4 years, they must return to their country of origin for 3 years before applying to return to Thailand again. ${ }^{31}$

The expense of obtaining a work permit varied hugely, from $\sim 1,000$ to $\sim 4,000$ Baht (US\$30-121) (this expense might be even higher if the cost of using private intermediaries were included), according to the type of work and length of stay (3, 6 , and 12 months). Hall suggested that the entire price of the MOU process, including the cost of broker support services, might be up to US\$1,100 per person. ${ }^{31}$ It should be noted that the law does not clearly specify who is responsible for this cost, migrant workers or employers. The ILO reported that some employers avoid responsibility for this cost by paying for the work permit in advance and then deducting the value from their employees' salaries. ${ }^{28}$

\section{Health protection}

One of the key measures aiming to protect health of migrants is a provision of public health insurance. In principle, uninsured migrants are still able to receive treatment at public hospitals, but the patients are obliged to pay the treatment expense according to the ability to pay. This topic encompasses two important subthemes: 1) characteristics of insurance for migrants and 2) confusion regarding the scheme after the coup.

\section{Characteristics of the insurance for migrants}

Thailand achieved UHC in 2002, through three main insurance schemes: 1) the Universal Coverage Scheme (UCS) for ordinary Thai nationals, 2) the Civil Servant Medical Benefit Scheme (CSMBS) for Thai civil servants, and 3) the Social Security Scheme (SSS) for workers in the formal private sector. $^{32}$ The key characteristics of these insurance schemes are presented in Table 2.

Legal immigrants working in the formal sector are covered by the SSS. However, MOU and NV migrants are 
Table 2 Characteristics of the main health insurance schemes for Thai citizens

\begin{tabular}{|c|c|c|c|c|c|c|}
\hline Scheme & $\begin{array}{l}\text { Population } \\
\text { coverage }\end{array}$ & $\begin{array}{l}\text { Financing } \\
\text { source }\end{array}$ & Benefit package & Purchaser & $\begin{array}{l}\text { Purchasing } \\
\text { mechanism }\end{array}$ & $\begin{array}{l}\text { Providers and } \\
\text { access to service }\end{array}$ \\
\hline $\begin{array}{l}\text { Social Security } \\
\text { Scheme (SSS) }\end{array}$ & $\begin{array}{l}\text { Private sector } \\
\text { employees, } \\
\text { excluding } \\
\text { dependents } \\
\text { (16\% of population) }\end{array}$ & $\begin{array}{l}\text { Tri-partite } \\
\text { contribution: } \\
\text { I.5\% of salary, } \\
\text { equally raised } \\
\text { by employer, } \\
\text { employee, and } \\
\text { government }\end{array}$ & $\begin{array}{l}\text { Comprehensive: } \\
\text { outpatient, } \\
\text { inpatient, accident } \\
\text { and emergency, } \\
\text { high-cost care }\end{array}$ & $\begin{array}{l}\text { Social Security } \\
\text { Office, Ministry } \\
\text { of Labor }\end{array}$ & $\begin{array}{l}\text { Contract model: } \\
\text { Inclusive of capitation } \\
\text { for outpatient and } \\
\text { inpatient services }\end{array}$ & $\begin{array}{l}\text { Registered public and } \\
\text { private competing } \\
\text { contractors }\end{array}$ \\
\hline $\begin{array}{l}\text { Civil Servant } \\
\text { Medical Benefit } \\
\text { Scheme (CSMBS) }\end{array}$ & $\begin{array}{l}\text { Government } \\
\text { employees plus } \\
\text { parents, spouse and } \\
\text { up to } 2 \text { children } \\
\text { aged }<20 \text { years } \\
\text { ( } 9 \% \text { of population) }\end{array}$ & General taxation & $\begin{array}{l}\text { Comprehensive: } \\
\text { slightly more } \\
\text { benefits than SSS } \\
\text { and UCS }\end{array}$ & $\begin{array}{l}\text { Comptroller } \\
\text { general's } \\
\text { department, } \\
\text { Ministry of } \\
\text { Finance }\end{array}$ & $\begin{array}{l}\text { Reimbursement } \\
\text { model: } \\
\text { Fee for service, } \\
\text { direct disbursement } \\
\text { to public providers } \\
\text { for outpatient and } \\
\text { Diagnostic Related } \\
\text { Groups (DRGs) for } \\
\text { inpatient }\end{array}$ & $\begin{array}{l}\text { Free choice of } \\
\text { providers, no } \\
\text { registration required }\end{array}$ \\
\hline $\begin{array}{l}\text { Universal } \\
\text { Coverage Scheme } \\
\text { (UCS) }\end{array}$ & $\begin{array}{l}\text { The rest of } \\
\text { population not } \\
\text { covered by SSS and } \\
\text { CSMBS ( } 75 \% \text { of } \\
\text { population) }\end{array}$ & General taxation & $\begin{array}{l}\text { Comprehensive: } \\
\text { similar to } \\
\text { SSS, including } \\
\text { prevention and } \\
\text { health promotion } \\
\text { for the whole } \\
\text { population, and } \\
\text { high-cost care }\end{array}$ & $\begin{array}{l}\text { National Health } \\
\text { Security Office } \\
\text { (autonomous } \\
\text { agency the } \\
\text { board of which } \\
\text { is chaired by } \\
\text { the Minister of } \\
\text { Public Health) }\end{array}$ & $\begin{array}{l}\text { Contract model: } \\
\text { Capitation for } \\
\text { outpatients and global } \\
\text { budget plus DRG for } \\
\text { inpatients }\end{array}$ & $\begin{array}{l}\text { Registered contracted } \\
\text { provider, notably } \\
\text { district health system }\end{array}$ \\
\hline
\end{tabular}

Notes: Data from Tangcharoensathien et al ${ }^{32}$ and Evans et al. ${ }^{45}$

mostly engaged in low-skilled work in the informal sector. Therefore, they are not entitled to the SSS. In summary, migrants who are not entitled to the SSS are 1) illegal/ undocumented migrant workers, 2) legal migrants working in the informal sector, and 3) dependents of migrant workers. To fill this gap, in 2004 the MOPH introduced the "HICS" to insure migrants who are not covered by the SSS. Note that the MOPH does not have a specific legal instrument (such as an act or decree) that can force migrants to enroll in the HICS and punish employers if they refuse to purchase the insurance card for their employees. In essence, the policy is not as "compulsory" as it was intended to be.

(Interviewer: What factors do you consider to be creating a bottleneck hindering the operation of the migrant insurance at this moment?) We need the insurance system to be supported by a legal instrument. Without a legal foundation, it is not possible to establish an authority to work on this issue in the long run. [M4]

The Health Insurance Group (HIG) is the main governing body of the HICS. It is an authority under the Office of the Permanent Secretary of the MOPH. The organization was not designed from the outset to manage the HICS. Furthermore, due to pressure from within the Thai bureaucracy, the HIG does not have the leeway to expand its human resource capacity because the civil servant post quota is limited, and this must be shared between all authorities under the MOPH. However, the HIG does have the capacity to hire temporary contract staff.

There are only 10 staff members in the office. Two of them have just resigned. I seriously want to resign too [...] and the big-picture policy (on migrants) is always fluctuating. This consumes much of our time since we need to adjust our work in accordance with each new policy. If the new policies were developed based on what we have done, this would lead to progress. But, nowadays, policy is always volatile. [M7]

The HICS applied premium-based financing, paid by the insured individuals. Currently, there are three subtypes of HICS: 1) the "1,600 Baht" (US\$49) card plus 500 Baht (US\$15) for a health check for adult migrants, 2) the "2,200 Baht" (US\$67) card plus 500 Baht (US\$15) for health check of adult migrants, and 3) the "365 Baht" card for children of migrant families, under 7 years of age, without the requirement of a health check. The difference between the "1,600 Baht" card and the "2,200 Baht" card was that the latter was introduced after the coup in 2014 (detailed in the subsequent sections). At the time of its inception, in 2004, the card price was 1,300 Baht (US\$39). In 2013, the price was increased 
to 2,200 Baht (US\$67) to fund the expansion of the benefit package to cover HIV/AIDS treatment. The year 2013 was also the time when the "365 Baht" card (US\$11) for migrant children was launched. The most distinctive feature of the MOPH announcement in 2013 was that it used the term "migrant," instead of "migrant worker." This meant that any migrant was able to buy the card regardless of his/her work permit, or citizenship, status. A key informant (M1) opined that the expansion of the benefit package and the availability of the "2,200 Baht" card to all migrants were part of the country's international image campaign, and this would serve as a tool to counter the allegation, from international organizations and other states, that Thailand was failing to tackle the problems of human trafficking.

Children and women are potential victims of human trafficking...That is why we made this policy enabling us to insure all migrants in Thailand. [...] and the "365 Baht" card is the country's Corporate Social Responsibility. [...] and if we take care of them well, once they return home, they will definitely wish to come back to us. [M1]

The benefit package of the HICS is comprehensive and covers outpatient care, inpatient care, emergency treatment, and health promotion activities without co-payment by the beneficiaries. However, there is a minimal exclusion list for some high-cost treatments, such as dialysis for chronic renal failure and treatment for psychotic diseases.

Prior to 2013, the majority of the revenue, from the sale of the cards and the health screening fee, was pooled at the hospitals where migrant workers were registered. Since 2013, the majority of the revenue (US\$27 or $56 \%$ of the health premium) has been pooled at the MOPH and managed centrally to facilitate the subsidization of high-cost treatments (re-insurance system). A migrant must pass a test for serious communicable diseases (the list specified in the Alien Work Act, see the "Economic necessity" section) before being insured. The contracted facilities are the district and provincial MOPH hospitals. ${ }^{33}$

Two interviewees suggested that the design of the HICS is problematic, particularly in terms of the health screening regulations and its financing system. This is because, with poor regulation and weak oversight from the MOPH, some hospitals refused to transfer the reinsurance portion for high-cost care to the MOPH. Besides this, the health check regulation that prohibits migrants from being insured due to certain health conditions could potentially result in a public health threat to society at large if migrants with these communicable diseases were left untreated; this would be a particular concern in the cases of elephantiasis or active tuberculosis.
Some hospitals are bluffing by not sending money (for high-cost procedures) to us (the MOPH). They may think that they have already sold a large number of cards so they don't want to pool the high cost with us. [M7]

I am one of those who is not convinced that we should force migrants to have a health screening. Even though, it sounds good, I know that a yearly health check does not benefit you that much. But if you take all of them to get insured, this is the best disease surveillance system. It is a win-win situation. Now it is as though you need to know whether a migrant has certain diseases and you ask him/her to pay you in order to get this answer. [M3]

A summary of the characteristics of the HICS is presented in Table 3.

\section{Confusion regarding the scheme after the coup}

In 2014, Thailand experienced a severe political crisis. The country was divided into a pro-government group and the opposition. In mid-2014, a coup d'état took place. The coup leader announced that a coup was required to prevent potential clashes between the two political groups. Shortly after the coup, a large number of illegal/undocumented migrants returned to their home countries, particularly Cambodian migrants. This happened because at the time of the political crisis there were reports that the pro-government group had hired Cambodian migrants to attack its opposition, and there were rumors that illegal migrants would be arrested or even killed by the junta. ${ }^{34,35}$ This situation led to a massive exodus of 170,000-220,000 Cambodian migrants to the border. The exodus continued despite denials of any official crackdown from the Thai junta. ${ }^{35}$ A huge outflow of Cambodian migrants produced negative effects on both the Thai and Cambodian economies. The Cambodian labor market was not able to absorb, and provide job opportunities to, those (self) deported migrants. This meant a loss of more than US\$1 million per day in cash flow between the two countries. ${ }^{34}$

I am more than happy to see more than 100,000 Cambodian migrants fleeing out of the country. It makes the government realise that they (migrants) are not voiceless. I wish Thai people would petition the government too. [M2]

To resolve this problem, the junta officially set up the "One Stop Service" (OSS) policy in four provinces along the Thai-Cambodian border. The Order No.70/2557 stated that Cambodian migrant workers who wish to work in Thailand, either newcomers or returnees, must be registered with 
Table 3 Characteristics of the Health Insurance Card Scheme for migrants

\begin{tabular}{|c|c|c|c|c|c|c|}
\hline Card & Premium & $\begin{array}{l}\text { Length of } \\
\text { coverage }\end{array}$ & Beneficiaries & $\begin{array}{l}\text { Beginning } \\
\text { from }\end{array}$ & Benefit package & Legal basis \\
\hline $\begin{array}{l}\text { Health Insurance } \\
\text { Card for migrants }\end{array}$ & $\begin{array}{l}2,200 \text { Baht }+ \\
500 \text { Baht for } \\
\text { health check }\end{array}$ & I year & $\begin{array}{l}\text { All non-Thai } \\
\text { populations, except } \\
\text { for tourists, and } \\
\text { Caucasian foreigners }\end{array}$ & January 15,2013 & $\begin{array}{l}\text { Outpatient, inpatient, and health } \\
\text { promotion, disease prevention } \\
\text { services (including HIV/AIDS } \\
\text { treatment, and other high-cost }\end{array}$ & $\begin{array}{l}\text { The Cabinet } \\
\text { Resolution on } \\
\text { January } 15,2013\end{array}$ \\
\hline $\begin{array}{l}\text { Health Insurance } \\
\text { Card for migrant } \\
\text { children }\end{array}$ & 365 Baht & I year & $\begin{array}{l}\text { Migrant child aged } \\
<7 \text { years }\end{array}$ & January I5, 2013 & $\begin{array}{l}\text { care; excluding renal replacement } \\
\text { therapy for chronic renal failure } \\
\text { and treatment for psychosis and } \\
\text { drug dependence) }\end{array}$ & \\
\hline $\begin{array}{l}\text { Health Insurance } \\
\text { Card for migrant } \\
\text { workers }\end{array}$ & $\begin{array}{l}\text { I,600 Baht + } \\
500 \text { Baht for } \\
\text { health check }\end{array}$ & I year & $\begin{array}{l}\text { Migrants who } \\
\text { registered with the } \\
\text { One Stop Service by } \\
\text { October } 31,2014\end{array}$ & July 7,2014 & $\begin{array}{l}\text { Outpatient, inpatient, and health } \\
\text { promotion, disease prevention } \\
\text { services (including HIVIAIDS } \\
\text { treatment, and other high-cost } \\
\text { care; excluding renal replacement } \\
\text { therapy for chronic renal failure } \\
\text { and treatment for psychosis and } \\
\text { drug dependence) }\end{array}$ & $\begin{array}{l}\text { The Order of the } \\
\text { National Council } \\
\text { for Peace and } \\
\text { Order (NCPO) in } \\
2014\end{array}$ \\
\hline
\end{tabular}

Notes: Data from Health Insurance Group ${ }^{33}$ and National Council for Peace and Order. ${ }^{36}$

the OSS. ${ }^{36}$ Upon registration, they would receive a health check and a work permit. The OSS was shortly expanded to cover the whole country with an aim to register "all" illegal/ undocumented migrant workers and dependents (plus legal migrants whose work permits had expired) within a given period (June 25, 2014, to October 31, 2014). ${ }^{37}$ The key features of the OSS are as follows:

First, it required the MOI, the MOL, and the MOPH to work together in designated places within a province, such as city halls, hospitals, or stadiums, to facilitate the registration process, but the essence of the work remained unchanged: illegal/undocumented migrants must 1) be issued with the " 00 " ID card, 2) be issued with a work permit, and 3) pay for health insurance.

Second, the junta explicitly declared that there would not be any further extension of the OSS after October 31, 2014. Illegal/undocumented migrants failing to register with the OSS by October 31, 2014, were subject to deportation and Thai employers, who refused to take their undocumented/ illegal migrant employees to the OSS, would be fined or imprisoned.

Third, the OSS targeted only "migrant workers" and "dependents" from CLM nations. However, it did not specify a definition of "dependents" to be covered by this measure.

Fourth, the OSS initially aimed that the NV process would be completed by March 31, 2015. However, because the NV process was greatly delayed, a number of registered migrants were unable to obtain a valid passport within the given deadline. ${ }^{38}$ Therefore, the government opened a second round of OSS in mid-2015.

Fifth, the MOPH reduced the price of the health check from 600 Baht (US\$18) to 500 Baht (US\$15), and the price of the health insurance card from 2,200 Baht (US\$67) to 1,600 Baht (US\$49) in order to attract more migrants to be enrolled in the insurance scheme. Although the 2013 HICS policy was relatively open to undocumented/illegal migrants, the number of the card holders was very low. As of December 2013, 12 months after the Cabinet Resolution came out, there were only 66,000 card holders, far from its target of 1 million. ${ }^{39}$ The reduction of the card price, among other things, made the number of insured migrants expand to $\sim 1.5$ million. ${ }^{7}$ However, the National Council for Peace and Order (NCPO) did not clearly specify whether the 2013 HICS policy (2,200 Baht card) was still valid, that is, it was not clear whether or not migrants who failed to be registered with the OSS were still eligible to be insured.

The government used to say that they will be able to clear all illegal migrants within two months, which I told them was impossible. See, then they extended [...] and there exist problems in the implementation, you can recall the Burmese guys that were accused of killing a British girl [During the interview period, there was news reporting that two British backpackers were murdered in Thailand by Burmese migrant], they still have not yet joined the OSS. Like the issue of dependants, to what extent will we cover them? [...] and I believe that even if you ask the government, they cannot answer. [M3] 


\section{Discussion}

This study might be one of the first studies that shed light on the dynamicity and evolution of migrant policies in Thailand. It is obvious that policies relating to migrants in Thailand are intertwined with multiple ministries and political actors in a context shaped by both local and international politics.

As proposed by Leichter, exogenous factors such as 1) situation factors, 2) structural factors, 3) cultural factors, and 4) international factors always play a vital role in policy formulation and implementation. ${ }^{13}$ The evolution of policies regarding migrants in Thailand clearly supports Leichter's propositions; beyond that, the researchers discovered that these exogenous factors (eg, the threat of communism during the cold war, and allegations of human trafficking from international actors) are no longer truly "exogenous" in essence. On the contrary, they have gradually become subsumed into domestic Thai politics. Another key message from this study is that migrant health policy is not just a matter of "health." It is just a tiny jigsaw in the whole sphere of migrant policies, shaped by economic and security concerns. This message might be viewed as an important contribution to knowledge in migrant research arena not only in Thailand but also in other settings. The researchers not only presented the fieldwork findings but also incorporate these findings to construct a diagram/framework to provide better insights on migrant policies over time. Based on the researchers' synthesis, the history of migrant policies in Thailand can be divided into four phases/eras as depicted in Figure 2.

The first phase covered the period between the early 1900s and the 1990s. The country attempted to defend itself from the threat of colonialism, and this became more pronounced in the 1970s in light of a fear of communism stirred by the domino theory and close ties between the Thai military government and the United States. This is mirrored by Por Wor 337, which denied the jus soli enjoyment.

The second phase commenced in the economic boom in the early 1990s, during which the country faced a shortage of low-skilled labor. In this regard, "economics" was used as a justification, by all governments, to turn a blind eye to the illegal status of migrant workers.

The third phase began in 2004 when the " 00 " card was initiated and the health insurance scheme and the system for screening the health of migrants were introduced nationwide. The period between 2004 and 2013 saw the concept
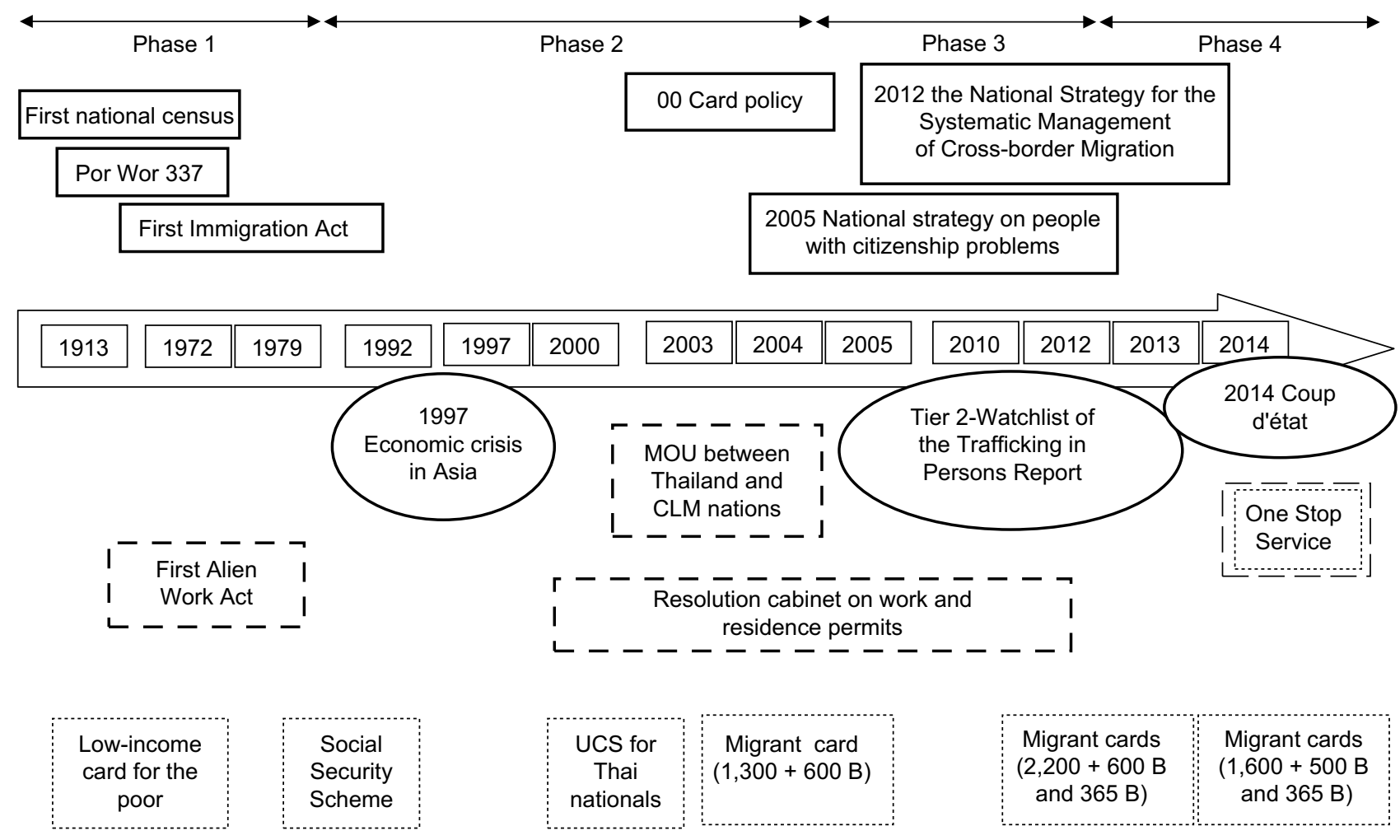

Figure 2 Evolution of migrant policies in Thailand.

Notes: Bold line, security policies; dashed line, employment policies; dotted line, health insurance policy; oval, external factors.

Abbreviations: B, Baht; CLM, Cambodia, Lao PDR, and Myanmar; UCS, Universal Coverage Scheme. 
of health security permeate into national migration policy, as evidenced by the introduction of the " 365 Baht card" for migrant children, and the fact that the scheme was open to "all" migrants. Nonetheless, it is difficult to assert that this change came from genuine humanitarian intentions on the part of the policy makers. As a matter of fact, pressure from civil society and the international community, particularly through allegations of human trafficking against Thailand, strongly pushed the country in this direction, and the revision of the HICS benefit package was used as a tool to counter these accusations.

The fourth era began in mid-2014, immediately after the coup, and continues today. Nationalist ideology has reclaimed its dominant position in the domestic policy sphere. The introduction of the OSS, on the one hand, is perceived as an attempt by the government to "sweep clean" the problems of illegal/undocumented migrants and to ensure that migrants extract the maximum benefit from the policy. On the other hand, regardless of whether or not migrants really participated in the major political conflicts of 2014, it is obvious that illegal/undocumented migrants were dragged into Thai political discourse. Immigration has been framed as a core policy topic, which can easily grasp public interest.

This trend has not only developed in Thailand but also in other regions where people are on the move. The 2015 immigration crisis in Europe caused a series of public debates between all parts of the political spectrum. ${ }^{40}$ Likewise, the UK Conservative Party campaigned in the 2015 election on the position that it would cap net migration into the UK and restrict the rights of migrants, purportedly, to protect the interests of UK taxpayers. The Party received strong support from the public despite the criticism on a lack of substantive evidence to support claims that migrants are undermining the interests of UK citizens. ${ }^{41}$

Interestingly, none of these changes in migrant policies have tackled structural problems of inward migration in Thailand. The key changes in the policies up to this point have only focused on the adjustment of the card price and the re-opening of the registration process. Looking superficially, the OSS, which requires all relevant authorities to work "simultaneously" in the "same" venue, seemed to have been a successful measure at the end of October 2014: the number of registered CLM migrants increased exponentially. ${ }^{7}$ However, one might argue that this success has not been due to the OSS per se but instead resulted from widespread fear of the junta. However, it is difficult to claim that the work carried out between the rewriting of policies has truly been integrated across the three relevant ministries (Interior, Labor, and Health). The root causes of irregular cross-border migration have not been addressed. The only measure that seems to be an innovation in promoting legal crossing is the MOU policy with the CLM countries, but this still requires much more work on its operational details. ${ }^{7}$

Besides this, policy makers at times acted like streetlevel bureaucrats in the way that they reacted and adapted to changing environments falling under their discretionary power without addressing the root causes of the problems. One example of this is the restriction of permitted jobs for migrants. Despite repeatedly expending significant effort to amend laws and regulations regarding job restrictions, and to implement a long-term national plan regarding job recruitment, previous governments consistently used cabinet resolutions as "temporary" solutions because using resolutions was an easier way to create change than amending the Act through formal legislative processes. It seems that successive governments used this temporary measure on a permanent basis.

In addition, MOPH has had a subordinate role in decision-making, in relation to the other relevant ministries. Particularly during the OSS period, the basic requirement of enrolment in HICS was registration with the MOI. This implies that the MOI has the primary responsibility and is the dominant agency in all stages of migrant registration. It is very likely that the system may miss some illegal/undocumented migrants due to migrants' fear of being prosecuted if their presence is revealed to security officers. This situation mirrors that in some European countries. In Spain, although the insurance system is open to all migrants, a number of undocumented/illegal migrants choose not to show up at the municipality for fear of being deported. ${ }^{42}$

The lack of power of the MOPH is not the only explanation for the implementation problems. Internal bureaucratic inefficiency and outdated public administration structures are key challenges. As was expressed in the interview, the HIG seemed to lack skilled staff and know-how necessary to effectively manage the insurance scheme. The MOPH bureaucracy cannot respond promptly to dynamic changes in migration policies. Since it serves dual functions as both "purchaser" and "provider" of services, the MOPH can be criticized for the lack of financing accountability and transparency. ${ }^{43}$

It does not mean that all previous and existing measures to tackle the problems of migration are totally wrong; however, there is still significant room for improvement. This study can put forward some key policy recommendations, as follows. First, all government sectors should clarify whether 
the country intends to provide insurance cover for "all" migrants on Thai soil or just "migrant workers." Second, health protection should be granted the same importance as economic and national security concerns. This would require boosting the capacity of the MOPH to manage the HICS more effectively or, alternatively, overhauling the system by merging the HICS with the UCS (where the National Health Security Office is the implementing body). Third, the government should establish supporting mechanisms to fill the gaps between policies. For example, to date, there has been no measure explicitly designed to deal with those who failed the NV and was able to return to their home country. Similarly, there is no clear measure to ensure proper treatment for uninsured migrants who failed to pass the health check (it is estimated that migrants with tuberculosis constituted $\sim 1.8 \%$ of all migrants undertaking the health check). ${ }^{44}$ All of these recommendations can be a starting point for further policy negotiations. Further studies are necessary to explore the feasibility of these options.

This study faced some limitations. First, because migrant policies in Thailand are greatly dynamic, and the timeline for fieldwork and writing was quite limited (between mid2014 and mid-2015), it was difficult to capture all the latest changes in migrant policies.

Second, with a medical background of all authors, although this research attempted to obtain data from all key policy lenses, most information acquired from the interviews and literature review is bounded within a health care outlook. There are some societal angles, which might have substantial impacts on the design and evolution of the policies but have not been explored at length by this study (eg, what is the cost of the society if undocumented/illegal migrants are left uninsured? what are the benefits for Thai citizens from providing care for these migrants? what are the perceptions of Thai citizens toward undocumented/illegal migrants? and how does the Thai-Burmese history shape the design and the function of migrant policies in Thailand?). To explore these issues further, different research approaches are needed, such as ethnographic study, political science approach, economic analysis, and media research.

Third, this study has not captured views from local implementers and service users. Thus, it is difficult to establish whether all the points raised by (a small number of) the interviewees really took place in the field. In addition, further studies on local implementers and migrants are needed to address some key policy questions that have been left untouched, for insurance, whether and to what extent undocumented/illegal migrants are comfortable with the current card price.
Fourth, as this study is not a systematic review article, most references shown here did not pass through a quality appraisal process. The researchers opted to use interviews and narrative review as the main data collection techniques instead of a systematic review because, normally, a systematic review approach is more suitable for specific research question or hypothesis-testing objective, whereas this article aimed to present an overview of the whole sphere of migrant policies in Thailand.

Finally, as was mentioned earlier, the scope of this study was limited to CLM illegal/undocumented migrants who are potential beneficiaries of the HICS. There are other non-Thai populations that have not been explored, this is without considering the overlapping features/definitions between groups. Generalizations of the results of this study to a wider public should be made with caution.

\section{Conclusion}

The evolution of migration policies reflects the power play between different state authorities: 1) the MOI, which focuses on maintaining national security, 2) the MOL, which has an economic interest in light of labor shortages, and 3 ) the $\mathrm{MOPH}$, which is responsible for the protection of public health. The HICS is part of the complex migration policy nexus, within which, the MOPH seems to have subordinate policy-making position. Migration health policy in Thailand is greatly dynamic and is very sensitive to both domestic and international factors, such as changes in the government and allegations of human trafficking in global policy dialogue. Ideally, the HICS is supposed to function seamlessly with other policies relating to migrants, particularly the process of issuing a work permit and the NV. In practice, there are a number of operational constraints. These include bureaucratic inefficiency, poor law enforcement, and lack of intersectoral coordination. In 2014 the OSS was endorsed by the junta to fill the gaps in migration policy between the three relevant authorities and to respond to the exodus of migrant workers. Although the OSS was successful in registering a large number of undocumented/illegal migrants, the functions between different ministries have not been integrated in practice, and there is a lack of other supporting mechanisms to comprehensively tackle problems regarding the rights and legal status of migrants.

\section{Ethical approval and consent}

This study has been approved by the ethical committee of the Institute for Development of Human Research Protection, Thailand (letter number IHRP: 1778/2014). Written consent was obtained from the interviewees. The study contains 
information about the interviewees' characteristics in an anonymous fashion. All interviewees gave written consent to the researchers to have their quotes and characteristic information presented in the study.

\section{Availability of data and materials}

The data sets generated, and/or analyzed, during the current study are available from the corresponding author on reasonable request through e-mail.

\section{Acknowledgments}

The authors would like to thank Professor Anne Mills from London School of Hygiene and Tropical Medicine, UK, and Dr Suwit Wibulpolprasert from the Ministry of Public Health, Thailand, who continuously provided valuable advice to the authors. They are also very grateful for the support received from IHPP staff. The language editing by Mr Alex Dalliston is much appreciated.

This study was supported by the Health Insurance System Research Office of the Health Systems Research Institute (HSRI), Thailand. The publication fee was also supported by the HSRI (letter number 59-026).

\section{Author contributions}

RS and WP contributed to data collection. All authors contributed toward data analysis, drafting and critically revising the paper, gave final approval of the version to be published, and agree to be accountable for all aspects of the work.

\section{Disclosure}

The authors report no conflicts of interest in this work.

\section{References}

1. International Organization for Migration. World Migration Report 2010. The Future of MIGRATION: BUILDING CAPACITIES for Change. Geneva: IOM; 2010.

2. World Health Organization: 60th Assembly. Resolution WHA60.26 Workers' Health: Global Plan of Action. Geneva: WHO; 2007.

3. World Health Organization: 61st Assembly. Resolution WHA61.17 Health of Migrants. Geneva: WHO; 2008.

4. Macpherson DW, Gushulak BD, Macdonald L. Health and foreign policy: influences of migration and population mobility. Bull World Health Organ. 2007;85(3):200-206.

5. Tangcharoensathien V, Mills A, Palu T. Accelerating health equity: the key role of universal health coverage in the Sustainable Development Goals. BMC Med. 2015;13(1):1-5.

6. Kantayaporn T, Sinhkul N, Ditthawongsa N, Chinworasopark P, Silwutthaya S, Phanathanasarn K. Estimation of Transnational Population for Developing Maternal and Child Health in Bangkok. Nonthaburi: HISRO; 2013.

7. Office of Foreign Workers Administration. Statistics of cross-border migrants with work permit in Thailand as of May 2015; 2015 [cited June 15, 2015]. Available from: http://wp.doe.go.th/wp/images/statistic/ sm/58/sm0558.pdf. Accessed June 15, 2015.

8. Martin P. The Economic Contribution of Migrant Workers to Thailand: Towards Policy Development. Bangkok: International Labour Organization; 2007.
9. Suphanchaimat R, Wisaijohn T, Seneerattanaprayul P, et al. Evaluation on System Management and Service Burdens on Health Facilities under the Health Insurance for People with Citizenship Problems. Nonthaburi, Thailand: International Health Policy Programme; 2013.

10. Srithamrongsawat S, Wisessang R, Ratjaroenkhajorn S. Financing Healthcare for Migrants: A Case Study from Thailand. Nonthaburi, Thailand: Health Insurance System Research Office/ Health Systems Research Institute; 2009.

11. Paisanpanichkul D. Policy Recommendations for Developing Health Insurance for Stateless/Nationalityless Population in Thailand. Nonthaburi, Thailand: Stateless Watch/Health Insurance System Research Office; 2008.

12. Paitoonpong S, Chalamwong Y. Managing International Labor Migration in ASEAN: A Case of Thailand. Bangkok: TDRI; 2011.

13. Leichter HM. A Comparative Approach to Policy Analysis: Health Care Policy in Four Nations. Cambridge: Cambridge University Press; 1979.

14. Thai Immigration Bureau. Immigration Act in the name of his Mejesty King Bhumibol (enacted on the 24th of February B.E. 2522); 2004 [cited April 15, 2015]. Available from: http://www.immigration.go.th/ nov2004/en/doc/Immigration_Act.pdf. Accessed April 15, 2015.

15. Napaumporn B. Analysis of Nationality Verification of Migrant Workers in Thailand: The Case of Workers from Cambodia, Lao PDR and Myanmar. Nakorn Pathom: Faculty of Graduate Studies, Mahidol University; 2012.

16. Teerawekin L. State Building and National Building; 2009 [cited October 14, 2015]. Available from: http://www.manager.co.th/Daily/ ViewNews.aspx?NewsID=9520000048092. Accessed October 14, 2015.

17. Soitong $\mathrm{S}$. Persons born in Thailand but not acquiring Thai nationality; 2012 [cited October 14, 2015]. Available from: https://www.gotoknow. org/posts/503656. Accessed October 14, 2015.

18. Saisoonthorn P. Development of concepts on nationality and the efforts to reduce statelessness in Thailand. Refugee Survey Quarterly. 2006;25(3):40-53

19. Rijken C, Waas Lv, Gramatikov M, Brennan D. The Nexus between Statelessness and Human Trafficking in Thailand. 1st ed. Oisterwijk, the Netherlands: Wolf Legal Publishers; 2015.

20. The Human Rights Sub-Committee on Ethnic Minorities Stateless Migrant Workers and Displaced Persons. Policies and Measures to Tackle Problems of Migrant Workers. Bangkok: The Lawyers Council of Thailand; 2011.

21. US Department of State. Trafficking in Persons Report; 2012 [cited October 18, 2015]. Available from: http://www.state.gov/documents/ organization/192587.pdf. Accessed October 18, 2015.

22. Thai Civil Rights and Investigative Journalism. Risk of Thailand in being put in the black list of human trafficking report after 2 years in the watchlist as suspected by USA as source of illegal sex workers, migrant workers, and beggars; 2012 [cited October 18, 2015]. Available from: http://tcijthai. com/tcijthainews/view.php?ids=745. Accessed October 18, 2015.

23. Office of the National Security Council. National Strategy on the Systematic Management of Illegal Immigrants (the Cabinet Resolution 24 April 2012). Bangkok: NSC, Thai Government; 2012.

24. The Government of Thailand. Royal Decree: Prescribing works relating to occupation and profession in which an alien is prohibited to engage, B.E.2522 (1979); 1979 [cited October 21, 2015]. Available from: http:// thailaws.com/law/t_laws/tlaw16075.pdf. Accessed October 21, 2015.

25. Pholphirul P, Rukumnuyakit P. Economic Contribution of Migrant Workers to Thailand; 2008 [cited October 21, 2015]. Available from: http://news.nida.ac.th/th/images/PDF/article2551/\%E0\%B8\%AD.\%E0 $\% \mathrm{~B} 8 \% 9 \mathrm{E} \% \mathrm{E} 0 \% \mathrm{~B} 8 \% \mathrm{~B} 4 \% \mathrm{E} 0 \% \mathrm{~B} 8 \% \mathrm{~A} 3 \% \mathrm{E} 0 \% \mathrm{~B} 8 \% \mathrm{~B} 4 \% \mathrm{E} 0 \% \mathrm{~B} 8 \% \mathrm{~A} 2$ $\% \mathrm{E} 0 \% \mathrm{~B} 8 \% \mathrm{~B} 0$. pdf. Accessed October 21, 2015.

26. Chantavanich S, Vungsiriphisal P. Myanmar migrants to Thailand: economic analysis and implications to Myanmar development. In: Lim H, Yamada Y, editors. Economic Reforms in Myanmar: Pathways and Prospects. Bangkok: IDE-JETRO; 2012: 212-280.

27. Thai Immigration Bureau. The Act on Alien's Work in the name of his Mejesty King Bhumibol (enacted on the 13th of February B.E. 2551); 2008 [cited March 15, 2015]. Available from: http://www.immigration. go.th/acts/act_alienwork2551.pdf. Accessed March 15, 2015. 
28. Archavanitkul K, Wachanasara K. The employment of foreign migrant workers according to the Act on Alien's Work (B.E. 2551) and the establishment of occupation list for migrants; 2008 [cited October 22, 2015]. Available from: http://www.colomboprocess.org/ posters $/ 141010171019$ Employment $\% 20$ of $\% 20$ migrant $\% 20$ workers $\% 20$ under $\% 20$ the $\% 20$ Working $\% 20$ of $\% 20$ Aliens $\% 20$ Act $\% 20$ $2008 \% 20$ and $\% 20$ the $\% 20$ list $\% 20$ of $\% 20$ occupations $\% 20$ allowed $\% 20$ to\%20foreigners.pdf. Accessed October 22, 2015.

29. ILO Regional Office for Asia and the Pacific. Review of the Effectiveness of the MOUs in Managing Labour Migration between Thailand and Neighbouring Countries. Bangkok: ILO; 2015.

30. Vasuprasat P. Inter-STATE COOPERATION on Labour Migration: Lessons Learned from MOUs between Thailand and Neighbouring Countries. Bangkok: ILO Regional Office for Asia and the Pacific; 2008.

31. Hall A. Experiences of Myanmar Migrant Workers in Thailand with the MOU Import Process. Nakorn Pathom: IPSR, Mahidol University; 2012.

32. Tangcharoensathien V, Patcharanarumol W, Vasavid C, et al. Thailand Health Financing Review 2010. Nonthaburi, Thailand: International Health Policy Programme; 2010.

33. Health Insurance Group. Health Card for Uninsured Foreigners and Health Card for Mother and Child. Seminar on measures and protocols of medical examination, insuring migrants and protecting maternal and child health. Best Western Grand Howard Hotel, Bangkok: Office of the Permanent Secretary, MOPH; 2013.

34. Thearith L. The Cambodian fallout from Thailand's coup; 2014 [cited November 9, 2015]. Available from: http://www.eastasiaforum. org/2014/06/27/the-cambodian-fallout-of-thailands-coup/. Accessed November 9, 2015.

35. Keck Z. 170,000 Panicked Cambodians Flee Thailand. ASEAN Beat; 2014 [cited November 9, 2015]. Available from: http://thediplomat. com/2014/06/170000-panicked-cambodians-flee-thailand/. Accessed March 3, 2016.

36. National Council for Peace and Order. Temporary measures to problems of migrant workers and human trafficking (Order No.70/2557). Bangkok: NCPO; 2014: 70/2557.
37. National Council for Peace and Order. Temporary measures to problems of migrant workers and human trafficking (Order No.118/2557). Bangkok: NCPO; 2014: 118/2557.

38. Prachatai. The Resolution Cabinet, which extends the nationality verification of migrant workers another 2 years, breaches the policies that aim to resolve legal status of migrant workers; 2016 [cited March 3, 2016]. Available from: https://prachatai.org/journal/2016/03/64385. Accessed March 3, 2016.

39. ASTV Manager Online. Ministry of Public Health fails to distribute health insurance card for migrants with 66 thousands distributed in 4 months; 2013 [cited June 21, 2014]. Available from: http://www. manager.co.th/qol/viewnews.aspx?NewsID=9560000156809. Accessed June 21, 2014.

40. Sanandaji T. Europe's Intensifying Immigration Debate; 2015 [cited November 12, 2015]. Available from: http://www.nationalreview. com/article/396177/europes-intensifying-immigration-debate-tinosanandaji. Accessed November 12, 2015.

41. Partos R. No immigrants, no evidence? The making of Conservative Party immigration policy; 2015 [cited November 12, 2015]. Available from: https://www.psa.ac.uk/insight-plus/no-immigrants-no-evidencemaking-conservative-party-immigration-policy. Accessed November 12, 2015.

42. Gray BH, van Ginneken E. Health care for undocumented migrants: European approaches. Issue Brief (Commonw Fund). 2012;33:1-12.

43. Tangcharoensathien V, Limwattananon S, Patcharanarumol W, Thammatacharee J, Jongudomsuk P, Sirilak S. Achieving universal health coverage goals in Thailand: the vital role of strategic purchasing. Health Policy Plan. 2015;30(9):1152-1161.

44. Bureau of Health Administration. Minutes of the Consultative Meeting on the Development of Migrant-Friendly Health Service (1/2558) on 23 January 2015. Nonthaburi: Ministry of Public Health; 2015.

45. Evans T, Chowdhury A, Evans D, et al. Thailand's Universal Coverage Scheme: Achievements and Challenges. An Independent Assessment of the First 10 Years (2001-2010). Nonthaburi, Thailand: Health Insurance System Research Office; 2012.
Risk Management and Healthcare Policy

\section{Publish your work in this journal}

Risk Management and Healthcare Policy is an international, peer-reviewed, open access journal focusing on all aspects of public health, policy, and preventative measures to promote good health and improve morbidity and mortality in the population. The journal welcomes submitted papers covering original research, basic science, clinical and epidemiological

\section{Dovepress}

studies, reviews and evaluations, guidelines, expert opinion and commentary, case reports and extended reports. The manuscript management system is completely online and includes a very quick and fair peerreview system, which is all easy to use. Visit http://www.dovepress.com/ testimonials.php to read real quotes from published authors. 